\title{
Derek Walcott's Omeros: A postcolonial Caribbean Epic
}

Amany Abdelkahhar Aldardeer Ahmed

\section{Abstract}

This paper reveals Walcott's attempt to penetrate the St.Lucian Caribbean culture, and to decipher the major social and political aspects that distinguish Omeros as a postcolonial work of literature. Omeros traces the history of St. Lucia from the colonial period to the postcolonial period to identify the unique qualities of the Caribbean society. It also holds a place as one of the best modern epics that reflect the postcolonial divisions and searches for the Caribbean identity. Omeros unfolds the postcolonial Caribbean history with the feelings of exploitation and ambivalence of the Caribbean people.

\section{The Purpose of the study}

The primary purpose of this paper is to present Walcott's Omeros as a Caribbean epic which demonstrates Walcott's quest to celebrate the Caribbean cultural identity and the history of St.Lucia in a modern epic. The poem identifies the Caribbean identity through demonstrating its different aspects of race, class, religion and nation. Omeros, then, concerns with the formation of the Caribbean community that extends beyond the community of St. Lucia. It explores postcolonialism and its effects on the characters who are always portrayed questing for their wholeness and identity.

${ }^{(*)}$ This paper is a part of PhD. thesis entitled: " Multiculturalism and the Quest for a Cultural Identity in the Poetry of Derek Walcott". Supervised by Prof. Fawzia M. Aly Gadalla - Faculty of Arts-Sohag University \& Prof. Ahmed Abdellah Elsheemi- Faulty of Languages Bani-Suef University \& Prof. Catherine A. John- Department of English- Faculty of Arts, Oklahoma University \& Dr. Thana A. Elkady- Faculty of Arts-Sohag University. 


\section{Derek Walcott's Omeros: A postcolonial Caribbean Epic}

\section{Review of the Literature}

Many writers deal with Omeros as an outstanding poetic work. Reading Walcott's Omeros from a postcolonial point of view, reflects the text's interconnection of issues of race, identity, migration with cultural production. Line Henriksen deals with Omeros as a postcolonial epic in his book, Ambition and Anxiety: Ezra Pound's Cantos and Derek Walcott's Omeros as Twentieth-Century Epics. He says: "Omeros.... deals with themes of relevance to postcolonial discussion of New World identity (Henriksen 237). The poem is a combination of standard English and Creole Caribbean. In The Hybrid Muse: Postcolonial Poetry in English, Jahan Ramazani indicates: "Forced and voluntary migration, crossings of one people with another, linguistic Creolization and racial miscegenation - these are the sorts of displacements, wanderings, and intermingling that poetic metaphor can powerfully encode in the fabric of post colonial text" (69). Walcott writes in the language of his people to convey his views of identity to his fellow Caribbean people. As a post-colonial writer, he writes with the notion of intervention with regard to the question of language. In examining Walcott's Omeros in a post-colonial context, it is important to refer to the fragmented Caribbean society. In Castings: Monuments and Monumentality in poems by Elizabeth Bishop, Robert Lowell, James Merrill, Derek Walcott, and Seamus Heaney Guy Rotella reflects the uniqueness of Omeros and says: "The poem rejects many of the genre's defining conventions in ways that revile, remember, and rewrite them while revising their values"(161).

\section{Methodology}

As Omeros is a reflection of the Caribbean culture, it is important to understand the definitions of the related cultural studies. Being a postcolonial writer, Walcott employs Edward Said's definition of culture in dealing with the St.Lucian cultural background. For Said, "cculture' means . . . all those practices, 
like the arts of description, communication, and representation, that have relative autonomy from the economic, social, and political realms and that often exist in aesthetic forms, one of whose principal aims is pleasure" (Culture and Imperialism xii). In Omeros, Walcott attempts to penetrate the St.Lucian Caribbean culture, and to decipher the major social and political aspects that distinguish it as a postcolonial Creole culture. Hence, the language and the forms of the Caribbean West Indies help carrying out the poet's cultural themes and ideas.

\section{Discussion}

With the publication of Omeros(1990), Walcott has received fame and great success, especially after he received the Nobel Prize for literature in 1992. Omeros reveals the influences and the motives of the Caribbean multicultural and interconnected commonalities among characters of different backgrounds. It develops the connection among various peoples, cultures, languages and histories. The poem's main concern is to find reconciliation of these conflicts. In order to understand Omeros, one should first understand St. Lucia's fragmented heritage and the long life of colonialism.

Omeros is a celebration of the Saint Lucian Caribbean community as it is concerned with the reformation of St.Lucia after hundreds of years of European colonial occupation. The story of Omeros revolves mainly around Helen, a very attractive woman who was formerly a housemaid for Dennis and Maud Plunkett and she appears at the beginning of the poem to be out of work. Walcott refers to her when he says: "a woman with a madras head-tie/ but the head proud, although it was looking for work/ I felt like standing in homage to beauty"(Omeros 23). Walcott's description of Helen demonstrates not only her beauty, but also her interconnected relationships with other characters in the poem. Helen lives with Achille, however, she was in love with Hector. The 
relationship among the three characters became complex after Helen's pregnancy, especially she was not sure who is the father of the unborne baby. "Helen's unborn baby is a symbol of a new, transformed life ahead....the baby is meant to symbolize the hope of the future, but what future awaits fishermen who can no longer live by their sails?"(Roy 61). The poem allows the reader to have a clear glimpse of the way Walcott perceives the Caribbean society culturally and emotionally.

The characters within Omeros develop to represent the multicultural and fragmentary groups of the St.Lucian society. They vary from the poor, Creole-speaking and the middle class Caribbean who suffer from the effects of colonialism. Walcott made good use of classical literature and the Greek Methology through employing the same Greek names as Achille, Hector, Philocetet, Afolable and Helen. These characters have shared experiences with the Greek. However, the characters in Omeros are not heroes but rather common people. Moreover, Walcott responds to the Caribbean use of Creolization and changes in the name of his characters, for example: the protagonist "Achilles" in the classical epic becomes "Achille" in Omeros. Walcott's politics of multiculturalism and the search for cultural identity are clearly depicted in Omeros. The effect of postcolonialism could be seen in Walcott's narrative of Saint Lucians' resistance to the colonial control.

The characters in Omeros are ordinary people and some are seen as marginalized and their main concern is the quest for identity, self-realization and community. Each character is portrayed in a way to represent a Caribbean theme. For example, the poem investigates the theme of exile and Creolization through portraying characters as Major Plunkett and Philocetete. The poem then reflects a glorification of Africa as the home country of the main character, Achille and 
it represents a means of salvation and self-realization. The characters are interconnected with each other and "history" connects them together. For instance Plunkett is interested in writing the history of Helen:

Helen needed a history,

That was the pity that Plunkett felt towards her.

Not his, but her story. Not theirs, but Helen's war.

The name, with its historic hallucination, brightened the beach; the butterfly, to Plunkett's joy, twinkling from myrmidon myrmidon, from one sprawled tourist to another. Her village was Troy,

its smoke obscuring soldiers fallen in battle.

Then her unclouding face, her breasts Pitons,(30-1)

"Despite guilty feelings of responsibility, Plunkett entertains the idea of writing Caribbean history anew, inspired by the tribulations, and beauty, of his servant Helen"(Lagapa 118). History, for all the Caribbean people, symbolizes their identity, origin and heritage. For poor Helen, it is rather more important as it represents her origin and "that was the pity that Plunkett felt towards her". The denial of the Caribbean past and its culture is the major reason behind the displacement and rootlessness of the Caribbean people. They lived unrecognizable among the Western colonial cultures.

The story of Omeros opens with the love triangle between two different fishermen, Achille and Hector, and the beautiful maid Helen. The story continues to reveal Achille who loses Helen to Hector but at the end and after Hector's death she returned to him. Walcott makes good use of character portrayal and the use of symbolism is very evident in the poem. Helen, the beautiful and the pleasure-loving maid, represents the island of the St.Lucia, one of the West Indian major islands. She is pregnant by Achille or Hector and she is 
seen resisting Achille for naming her coming child an African name. The poem also reveals the story of Major and Maud Plunkett, the British/ Irish couple who employ Helen as a housemaid and the other characters of MaKilman, Philoctete and Sevenseas, who also move in Helen's life. Omeros, then, is an invitation to view modernism in the postcolonial milieu through creating postcolonial characters with different stories. The poem reveals much about St.Lucia's postcolonial wounds which are clear in the pain of these characters.

The opening of the work introduces the character of Philoctete who, while smiling for tourists who are taking his picture, tells them the story of making canoes. "The opening section of the poem makes clear, however, that Walcott will never allow any programmatic function of the rhythm to override its motive value. The sound and sense of the poem remain beautifully interwoven" (Callahan 14):

"This is how, one sunrise, we cut down them canoes."

Philoctete smiles for the tourists, who try taking

his soul with their cameras. "once wind bring the news

to the laurier-cannelles, their leaves start shaking the minute the axe of sunlight hit the cedars, because they could see the axes in our own eyes.(Omeros 3 )

Walcott makes good use of the rhythm in the poem. For example, "the three successive stresses of 'their leaves start shaking 'are a frequent rhythmic effect in Walcott's reading of the verse"(Barnard 81). The previous part of the poem presents the story of Philoctete, the first character in the poem who is different from the Greek Philoctete who was son of a king. In Omeros, he is a fisherman, who lives on the island of St. Lucia, telling stories to tourists and showing them his shin-wound as a way of begging them to have money. Philoctete's rotting 
wound makes him a bit of an outcast. He feels his wound is incurable as it is not just a physical wound, but it represents the psychological wound of losing the history of his ancestors and his grandfathers. "Walcott turns the wound into a resonant site of interethnic connection within Omeros, vivifying the black Caribbean inheritance of colonial injury and at the same time deconstructing the uniqueness of suffering"(Ramazani, "The Wounds of History 405). The following lines reveal more about the story of Philoctete, his suffering and his deep wound:

"Well, you must take it easy.

Go home and lie down, give the foot a lickle rest."

Phioctete, his trouser-leg rolled, stars out to seas

He believed the swelling came from the chained ankles

of his grandfathers. Or else why was there no cure?

That the cross he carried was not only the anchor's

but that of his race, for a village black and poor

as the pigs that rooted in its burning garbage,

then were hooked on the anchors of the abattoir.(Omeros 19)

The previous lines imply that the Philoctete's wound came from "the chained ankles of his grandfathers" and this answers the following question, "Or else why was there no cure?". Walcott stresses that the injury is deeper as it reaches the roots and the origin and this implies the difficulty of curing that injury. The story of Philoctete in the previous lines is well represented and portrayed so that it is very true to "a village black and poor". Therefore, the character of Philoctete represents a prototype of many of the Caribbean characters who suffer from physical and psychological wounds. "By appropriate the classical hero Philoctetes, Walcott not only 
gives new voice to the suffering of African Caribbean peoples under European colonialism and slavery, he fuses other prototypes of North and South, Old World and New in an astonishing hybridity that exemplifies the cross-cultural fabric of postcolonial poetry"(Ramazani, "The Wound of History" 405).

Omeros treats the wounds of many characters who were suffering at being uprooted from origin and identity. "Wounding is a key trope of the poem. Every principal character has some wound and the island itself does not escape this. The trees are about to be wounded, sacrificed, splashing blood... Wound variously represent Philoctete's suffering at being uprooted from country and name." (Barnard 80). Walcott completes the picture with presenting a detailed description of the St. Lucian milieu and the Caribbean people who live in a colonial exile:

These people were not resigned to living with garbage, drifting in numbed content as the filth narrowed the drains. They had not designed

the Attic ideal of the first slave-settlement, with sea-grapes for olives and black philosophers with clouds over their elbows. They had not laid out narrow-gauge pipes for buckets, but none for sewers. They had not sucked the cane till sugar was played out. Empires were swinish. These had splendid habits. (Collected Poems 63)

Using such sentences, "These people were not resigned/ to living with garbage" and "They had not designed/ the Attic ideal of the first slave-settlement", Walcott clearly wants to emphasize the fragmentation and rootlessness that Philoctete and most of the Caribbean characters suffer from. It is not only 
fragmentation of landscape but of language as well. Walcott, then, stresses that the colonizing world is seen as "filthy", "garbage", and "swinish", but the Caribbean people should not live in such an environment.

Omeros unfolds the postcolonial Caribbean history with the feelings of exploitation and ambivalence of the Caribbean people. It explores postcolonialism and its effects on the characters who are always portrayed questing for their wholeness and identity. Walcott concerns himself with developing diverse groups of characters that make up the St.Lucian society. One of such representative Caribbean characters is Achille, who is part of the folk cultural aspects of the African diaspora. Achille realized that he has lost much by not remembering his ancestors and he is about to forget his exciting reality as well. The protagonist of Omeros, Achille, is an incarnation of the Caribbean character in the sense of loss, loneliness and anger that leads him to a process of ambivalence and self-questioning in search for his true identity.

Achille is one of the main characters who is struggling in order to attain his identity and to re-establish his African roots. He travels back to Africa in order to regain his lost African identity. Although he went to Africa by his memory, Achille failed to connect with his ancestral original homeland. Although he is portrayed as a settled St.Lucian character, Achille is not satisfied and he seeks to find his lost identity which colonialism has erased. The character of Achille is a typical Caribbean character who suffered the fragmentation and the dislocation of the Caribbean colonial society. He starts to regain his lost identity only in his real community:

Achille, among those voluble leaves, his people, estranged from their chattering, withdrew in discontent. He brooded on the river. The canoe at its pole. 


\section{Derek Walcott's Omeros: A postcolonial Caribbean Epic}

doubled by its stillness, looked no different from its reflection, nor the pier stakes, nor the thick trees inverted at their riverline, but the shadow face

swayed by the ochre ripples seemed homesick for the history ahead, as if its proper place lay in unsettlement. So, to Achille, it appeared they were not one reflection but separate menone crouching at the edge of the spindley pierhead, one drowned under it, featureless in mien. (Omeros 140-41)

The previous lines show Walcott's description of Achille which reflects his shattered self as a Caribbean man and his lost history. In Epic of the Dispossessed: Derek Walcott's Omeros, Robert Hamner demonstrates that, "Day by day, Achille regains the details of his lost genealogy until he makes the connection between the modern world he has inherited and the tribe's unknown future" (77). Since he has mixed heritage, Achille cannot identify himself as a Caribbean or African. The impact of colonization is deep as it disrupts people's cultural identity and creates a fragmented nation with mixed feelings.

In his symbolic journey to Africa, Achille encounters his African father, Afolable. Furthermore, Achille cannot explain the meaning of his name, and even he is not able to remember the name given to him in Africa by his father, Afolable. The role of Achille's father is taken into deeper consideration as it symbolizes Africa and the pain of identity loss:

Achille's name dramatizes the arbitrariness of language because, like the names of many descendants of the African diaspora, it originates from a different cultural tradition than his body. . . - Achille's name, however, although it is twice exotic (Francophone, or French Creole, from 
Greek), does not refer to an 'immediate past' Achille might like to shed, but to a mythical one so remote he seems not to have heard of it.(Terada 29)

The name here implies the identity and the origin of the character. Being unable to explain the meaning of his name, Achille stresses the fact that he lost his connection with his real African identity and he replaced it with another one he adopted from his colonial life. Walcott skillfully imagined the conversation between Achille and his father as the following:

\section{AFOLABLE}

Achille. What does the name mean? I have forgotten the one

that I gave you. But it was, it seems, many years ago. What does it mean?

\section{ACHILLE}

Well, I too have forgotten.

Everything was forgotten. You also, I do not know. The deaf sea has changed around every name that you gave us; trees, men, we yearn for a sound that is missing. (Omeros 137)

Achille and his father felt the instability of language around them; they lost the oral tradition of their transplanted African ancestors. Moreover, those African-Caribbean people encountered forced enculturation into European colonial society which led to the instability of their language and identity. "This instability of language and text is partly a product of the fragmented nature of Caribbean history"(Bery 176). As the protagonist of the poem, Achille is aware of the loss of the Caribbean original language and its effect on the indigenous people. Hence, the poet succeeds in 
demonstrating both the Communal and the public feeling of wound in which language, history, heritage and origin are subjected to erasure and loss.

The dialogue between the characters has a major part in Omeros and reveals much about every character. "In Omeros... characters unfold mostly through the dialogue" (Fumagalli, The Flight 191). The dialogue between Achille and his father reveals the fragment of Achille's speech in spite of the extended period of his talk. Therefore, the technique of employing the dialogue between the characters and their extended speech helps in illuminating the characters and revealing their attitude and describing the point of view of each character. Achille's return to Africa frees him from colonization and becomes African. However, his return didn't restore his identity as he cannot explain the meaning of his name, nor can remember his old name in Africa. For Walcott "a return to Africa is impossible, for we cannot return to what we have never been"(Walcott Conversation 36). Achille is a representative of the African- Caribbean people whose quest for identity and self-realization incorporates Walcott's themes of multiculturalism and fragmentation.

Achille's African forefather, Afolable starts to explain to his son the importance of keeping one's name and identity. Afolable speaks on Walcott's tongue, addressing all the Caribbean people to stick to their origins and to be proud of their identity. "The relationship between Africa and the West Indies/ West Indians is also dramatized here via a dialogue.... The first thing Afolabe wants to know about his 'son' is both his name and what that name means"( Fumagalli, The Flight 196). The speech of the characters reveals the structures within which they are portrayed. "Omeros thus deals with themes of relevance to a postcolonial discussion of New 
World identity, yet it does so within a genre and tradition that is European rather than Caribbean" (Henriksen 237). Through presenting the dialogue between Achille and his father, Walcott demonstrates the importance of keeping one's name and identity. However, Achille's name reflects the Caribbean multiplicity of language:

\section{AFOLABLE}

A name means something. The qualities desired in a son, and even a girl-child; so even the shadows who called you expected one virtue, since every name is a blessing, since I am remembering the hope I had for you as a child. Unless the sound means nothing. Then you would be nothing.

Did they think you were nothing in that other kingdom?(Omeros 137)

These lines stress Walcott's aim to set the two major problems for the Caribbean; the problem of identity and the problem of language. This clarifies that the imposition of the colonized language (English language) and the negligence of the original language leads not only to the loss of identity, but also the loss of connection between the characters and their origin. The over repetition of the word "nothing" in the last two lines: "Unless the sound means nothing. Then you would be nothing / Did they think you were nothing in that other kingdom?", is skillfully used to stress the importance of language which implies the importance of identity. Afolable understands well the importance of identity and he puts it directly to all the Caribbean, that without identity, he said: "Then you would be nothing".

Reading Achille's situation from a postcolonial point of view indicates the difficulty of the connection or the understanding between the ancestor and the decedent. Achille 
struggled and failed to connect with his real father Afolabe and in the same way, Achille and his child from Helen has no connection. This struggle mirrors the struggle of the poet himself and all the Afro-Caribbean people who have to fight to gain recognition of their cultural identity and history. The structure employed in the poem reveals the interwoven stories between the past colonial history and the postcolonial future of the West Indies. In this way, the character of Achille changed over the time as it differs according to the society he finds himself in. Achille, then, is an example of the Caribbean black who have two dimensions; white and black. According to Fanon: "The black man possesses two dimensions: one with his fellow Blacks, the other with the Whites. A black man behaves differently with a white man than he does with another black man" (Fanon 1). This is the case with Achille who is portrayed searching for his African origin and when he met his African father, he forgot his name and failed to communicate with the people of his origin.

The feelings of displacement and fragmentation prevail the postcolonial society and haunted its people in Omeros, where the Caribbean people have internalized these feelings. Achille is a good example of the Caribbean people who feel shattered between his past which resembles his origin and his future society. "After his retour from Africa, Achille, a newborn African Caribbean, attempts to accommodate St Lucia as his home by developing a sense of rhizomic athomeness through the strategies of relation and Creolization; a sense which eliminates his alienation" (Zargarzadeh 718). Therefore, Achille adopts the language of the colonizer and he has assimilated the cultural values of the metropolis in the same way as Franz Fanon illustrates:

All Colonized people-in other words, people in whom an inferiority complex has been committed 
to the grave-position themselves in relation to the civilizing language: i.e., the metropolitan culture. The more the colonized has assimilated the cultural values of the metropolis, the more he will be escaped the bush. The more he rejected his blackness and the bush, the whiter he will become. (Fanon 3)

In the same way, Achille undergoes a journey of selfdiscovery to visit his African ancestors and attempts to discover his true identity and his original language. Eventually, the poet demonstrates that Achille's identity lies neither in African nor completely in the Caribbean, but in mixture between both.

Walcott utilizes the Creole linguistic features to reflect the Caribbean national identity. Moreover, he tries to bring new directions to the Caribbean poetry and endeavors to create a strong national poem within the Caribbean literary canon. Omeros follows the development of the characters and their internal struggle within the St. Lucian society which is full of diverse groups of the poor, Creole-speaking and some descendants of slaves. In Omeros, Walcott resists the postcolonial impulse through opening up the opportunities to the Caribbean vernacular. Walcott's racially mixed origin affected his sociolinguistic concerns in his poetry:

Walcott's own racially mixed ancestry is, in a sense, used as a metaphor of his poetic method. $\mathrm{He}$ is alternately repulsed and attracted by the European canon, unable to choose between the branches of his family tree. The sociolinguistic concerns raised by his work are also interpreted according to this dialectic; insofar as Walcott employs indigenous speech patterns and dialect he valorizes his African ancestry. (Callahan 100) 
Omeros is considered a good example of Walcott's use of multiple languages. Although The name "Omeros" is a derivation of the modern Greek pronunciation of Homer, Walcott gives the name a specific Caribbean meaning:

I said, "Omeros"

and $\mathrm{O}$ was the conch-shell's invocation, mer was

both mother and sea in our Antillean patios,

os, a gray bone, and the white surf as it crashes

and spreads its sibilant collar on a lace shore.

Omeros was the crunch of dry leaves, and the washes

That echoed from a cave-mouth when the tide is ebbed.

(Omeros 14)

" In these few lines Walcott expresses the multiple symbolic meanings of the name "Omeros": poetic inspiration, the sea as source of life, and the whole skeleton of the earth itself"(Zoppi 51). In these lines, mother hints at motherland and the sea is pivotal to life on St.Lucia. Walcott explains: "O" stands for the sea's invocation, "mer" is mother and sea, "os" is grey bone and sibilant surf. The lines show Walcott's desire to celebrate some aspects of the Caribbean's everyday life. Using "I" enhances the poem's narrative by allowing the reader to be familiar with the characters and the stories in the poem.

Walcott reveals his condemnation of colonialism and its prejudice in portraying the characters of Plunkett and his wife, who came to the Caribbean society from the British Island and after a long period of time, they became a part of its culture. Plunkett is wounded as a soldier for the colonizer which aggravated his wound. "Major Plunkett's head wound, suffered during World War II in Africa, indexes both a condemnation of imperial conquest and a sense of guilt as a soldier of the empire"(Lagapa 118): 
This wound I have stitched into Plunkett's character.

$\mathrm{He}$ has to be wounded, afflictions is one theme of this work, this fiction, since every "I" is a

fiction finally. Phantom narrator, resume:

Tumbly. Blue holes for his eyes. And Scottie wiser

when the shock passed. Plain men. Not striking. Not handsome. (Omeros 28)

As a multilayered and complex poem, Omeros handles different people, cultures and histories within the same society and its complexity is derived from the multiple story lines and the interconnections among the characters. Plunkett is one of the characters who is separated from his upper class history and culture and lived among the poor marginalized people. The use of dramatic monologue and narrative connects the characters together despite their multicultural origins. "The stories parallel and intertwine with one another in their development toward crisis and conclusion" (Barnard 9).

Like the major characters who live in the Caribbean society, Major Plunkett suffers from ambivalence and displacement and "England seemed to him merely the place of his birth". In her book, Exile and Return as Poetics of Identity in Contemporary Anglo-Caribbean Literature, Eleonora Natalia Ravizza reveals Plunkett's dilemma of identity:

The wound makes Major Plunkett a very complex and central figure, metaphorically opening his body to the other, as well as to a series of changes that he does not seem able to formulate his own words. Although appearing as a rigid character stuck with his privileges a white man, Plunkett is no less hybrid than other 
characters in the poem. Spending twenty years of his life on a Caribbean island has inevitably transformed him into a Saint Lucian.... Yet, this island .... Appears to Plunkett preferable to the relational landscape of his own homeland. (Ravizza 179)

Plunkett had to struggle to find a place in a postcolonial St.Lucian society. He is one of the Caribbean people who have many wounds caused by the fragmentation of his heritage. The character of Plunkett best resembles the feeling of ambivalence and displacement in Walcott's Omeros. He reflects the feeling of alienation and fragmentation that most of the Caribbean characters felt.

In regards to the Caribbean people's need to restore the Caribbean sense of identity, Walcott uses the Creole language in writing Omeros and realized that his role as a writer in a postcolonial island is to employ a language of his people rather than that of a colonizer. In Omeros, Walcott succeeds to create a national Caribbean consciousness through the use of the Caribbean language:

and the embers steam and hiss to the schoolboys' cries when he'd weep in the window for their tribal shame A shame for the loss of words, and a language tired

of accepting that loss and then all accepted.

That was why the sea stank from the frothing urine of surf, and fish-guts reeked from the government shed,(Omeros 248)

The employment of the line: "A shame for the loss of words, and a language tired" indicates the poet's deep grief and pain out of employing a different language in his poetry and not his 
native language. These lines attempt to demonstrate the poet's quest for hope and self-realization in the midst of the suffering and the despair of the colonial world. In addition, he condemns every aspect of the colonial society that aggravates the pain and the sorrow of his people. The word choice reflects the grim conditions of the Caribbean under colonialism such as: "cries", "weep", "shame" and "loss". The feeling of loss and shame prevailed the whole poem as well as the life of the Caribbean.

The characters in Omeros are all affected by "the cultural estrangement of the colonial epoch"(Fanon- Wreched 210). They are in need to be recovered from colonialism and they have to stick to their heritage and to be aware of the importance of their own culture and history. Furthermore, Walcott draws his characters to fit the personal and cultural situation of the Caribbean life in St.Lucia; they are portrayed as wounded, poor and with no identity:

who set out to found no cities; they were the found, who were bound for no victories; they were the bound, who leveled nothing before them; they were the ground.

he would be the soul of patience, like an old horse stamping one hoof in a pasture, rattling its mane or swishing its tail as flies keep circling its sores. (Omeros 22)

These lines match Walcott's major themes in Omeros; to quest and create a new Caribbean identity that is based mainly on the heritage and the origin of his characters. Through the use of repetition of "who" and the musical effect of the rhyming words, "found", "bound" and "ground" to describe the Caribbean people, Walcott stresses that "they were the 
ground". He focuses on the anchor of the Caribbean people that shape their identities and help molding their characters.

As a prototype and a typical Caribbean character, Achille, for instance, undergoes a quest for himself and for his community to celebrate his history and his African origin. In many situations he represents not only the poet himself, but also many Afro- Caribbean characters who left their origin to a new society to find no "cities" nor "victories". On the other hand, the origin of these characters is no longer appropriate for them. Colonialism and post colonialism turned them to be unfit here or there. In one of the most representative scenes of the distorted Caribbean character, Walcott reflects the feeling of Achille in his homeland, Africa:

And Achille felt homesick shame and pain of his Africa. His heart and his bare head

were bursting as he tried to remember the name of the river-and the tree-god in which he steered, whose hollow body carried him to the settlement ahead.

He remembered his sunburnt river with its spindly stakes and the peaked huts platformed above the spindles where thin, naked figures as he rowed past looked unkindly.(134-5)

The previous part follows Achille's cultural journey from colonial slavery to postcolonial independence. As a result, Achille turned to be a displaced person "whose hollow body carried him to the settlement ahead". While living in the Caribbean postcolonial society, Achille was eager to return back to Africa and when he went there through memory he "felt homesick shame and pain of his Africa". Therefore, 
Achille is a cultural product of colonialism and he is affected by the politics of difference of postcolonialism and the feelings of marginalization, self and cultural alienation. In his imaginary journey to Africa, Achille makes a connection between the two worlds, the old and the new. Consequently, he became a distorted figure and a misfit between these two worlds.

In Omeros, the characters are not heroes but rather common people: fishermen, sailors, workers and waitresses. Character portrayal is skillfully used in drawing the character of Helen and Achille, who both represent prototypes of the Caribbean people. Whereas Helen who was a waitress, represents the island itself with its beauty and resistance, Achille who was a fisherman represents one of Helen's admirers and he is tempted by her beauty and thinks it is his property. The description of Helen's appearance conveys much about St. Lucia in its colonial past, especially when Walcott says:

And he, feeling like a dog that is left

to nose the scarps of her footsteps, suddenly herad his own voice ringing over the street. People turned their heads at the shout. Achille saw the yellow dress fold into closing crowd. (Omeros 38)

Walcott's presentation of Helen conveys her beauty, pride and her search for independence. Helen's "yellow dress" which attracts Achille symbolizes her beauty and pride. "Helen's yellow dress-as it moves from class to cultural to gender cross-dressing in Omeros- functions as a destabilizing element in Walcott's approach to the binaries of race, gender, class, and culture that have been the legacy of colonial history in the Caribbean" (Paravisini 221). 
Therefore, the physical appearance of Walcott's characters reflect their psychological feelings.

As a symbol of St.Lucia, the portrait of Helen resembles the portrait of the landscape itself and the beautiful nature of the island. In one of the most representative parts of the poem. Helen is portrayed as a woman whose individual identity and humanness are erasable:

I saw how the surf printed its lace in patterns

On the shore of her neck, then the lowering shallows of silk swirled at her ankles, like surf without noise, (Omeros 14)

Walcott likens Helen's nick to the Caribbean shore and the silk around her ankle is like a quiet surf. She is always desired by all the characters around her. "Walcott's treatment of Helen interrogates analogy even more sharply. Walcott's Helen, like Homer's, is an object of great desire. Hector and Achille vie for sexual attentions" (Terada 189). As Helen represents the island of St.Lucia and how it resisted colonialism by all means, she is always seen as a resistant for any source of tyranny and violence. Most of the events in Helen's life reveal the painful conditions in her life . "This outline of events shows that Omeros covers a period of considerable turmoil in Helen's life. Because Helen's motivations remain enigmatic the ultimate resolution of the plot questions that enslave her seems formal rather than psychological"(Terada 196). Therefore, Helen incarnates the two sides of the island; the beautiful charming side and the resistant side against the evil forces. Walcott goes on to complete the scene of her resistance: 
Helen never turned,

Carrying the basket with both hands. Her stubbornness

Made him crazy. He caught up with her. Then he tried

Retrieving the basket, but she yanked it from him.

"You not my slave!" she said

He said, "My hands tired."

He followed her to that part of the harbour's rim, past the charcoal vendors, where the transports were ranged like chariots, blunt-nosed and glaring, with the hum of idling motors. She stooped, and in her deranged Fury screamed: "Leave me, little boy!"(Omeros 38)

St.Lucia is linked to Helen in her "stubbornness". The artistic portrayal of Helen draws a unique image of the island which is a cultural product of colonialism; it reflects the physical, intellectual, psychological and cultural responses of the colonial brutality. Walcott's use of the Caribbean vernacular and language is a good indicator of his interpretation of the Caribbean identity and culture.

Consequently, Walcott tries, in Omeros, to search for postemancipation of the Caribbean identity. He invites the reader through Omeros to envision the Caribbean history in a new and different way through the use of language and the choice of words. Indeed, Walcott's devotion to St. Lucia is reflected in many of his poems as it has an enormous presence. Through Omeros, Walcott succeeded in tracing the history of the Caribbean from its colonial origins to the present. He employs the folk speech, folk religion and dialect in Omeros and makes good use of the folklore and the costumes in describing his characters. In addition, the use of the Caribbean Creole in the poem stresses the identification of the poet and the Caribbean subject. The use of language carries and expresses the cultural identity of the St.Lucian society. Moreover, Walcott uses the epic form for 
Omeros to reflect the great influence of the five hundred years of colonialism in the West Indies and the long years of slavery and segregation that led at last to the emergence of the Caribbean cultural identity.

Although epic poetry and epics are increasingly rare in the modern poetry, Walcott has certainly accomplished uniqueness with Omeros through his use of Creole Caribbean language and the employment of the ordinary people in the poem. In his book Walcott's Omeros: A Reader's Guide, Don Barnard illustrates the reasons behind Walcott's choice of the Creole language in his epic:

Walcott has creolized the epic conventions to produce... an epic of the dispossessed. His protagonists are not kings or folk heroes but simple Caribbean folk... His vision is of a village beauty, Helen. His epic catalogues are not of warriors' names, but of fishermen, birds, trees... His narrator is a wanderer, searching for himself and a voice. Nevertheless, familiar epic traditions exist: the nostos or return home, the questioning of the ancestors." (11)

The startling accomplishment of the poem is that it deals with the Caribbean multicultural society and the cultural transformation of St.Lucia. What distinguishes Omeros as a national work of literature is that it concerns with politically and economically marginalized members of their society and helps in creating a culture of their own. Moreover, Walcott received the Nobel Prize for the uniqueness of creating a cultural identity for the Caribbean. Hamner expresses, "When Walcott accepted his Nobel prize for literature in 1992, he delivered a paean to the spirit that makes it possible for the descendants of slaves and 
indentured servants to generate a culture of their own" (Hamner, Epic of the Dispossessed 127). Unlike the traditional epics, Omeros does not have an epic hero. However, Walcott makes good use of the slaves and the servants whose actions were well portrayed as heroic. "But they crossed, they survived. There is the epical splendor" (Omeros 1990).:

My inspiration was impulse, but the major zeal

to make her the pride of the Battle of the Saints, her yellow dress on its flagship, was an ideal no different from mine. Plunkett, in his innocence,

had tried to change History to a metaphor in the name of a housemaid; I, in self-defence, altered her opposite. (Omeros 270)

Walcott speaks directly to the reader comparing his own style with that of Plunkett's attempt "to change History to a metaphor" and revealing a painful vision of the Caribbean multicultural identity. "Plunkett's way of coming to terms with St.Lucia/ Helen's past is explicitly condemned by Walcott when he draws a parallel between his own literary work and Plunkett's revisionist attempt" (Fumagalli, The Flight 212). The way of writing and the style of narrating the incidents of the poem reveals Walcott's attempt to reconstruct the past of the Caribbean culture.

Walcott is involved in the search for the Caribbean identity and the West Indian heritage. He recognizes the importance of the African ancestry of the black West Indian and his approach focuses on the Caribbean problems of cultural identity created by the colonial system. As a Caribbean literary piece, Omeros reflects the importance of colonialism in shaping 
the Caribbean literature. It tries to enlighten the Caribbean history and heritage and to reflect the impact of colonialism and postcolonialism on the characters. These characters are affected by the Caribbean hybridity and the multiculturalism of their origins. "Being hybrid subjects, but in very different relations with race, power, and language, all the homecoming characters in Omeros, are obsessed with the irretrievability of their origins and with a confrontation with their parental figures"( Ravizza 161).

The Post-colonial Caribbean society is featured prominently in Walcott's Omeros and it could be seen in a number of contradictions and in Walcott's narrative of Saint Lucians' resistance to the colonial contradictions which is evident in Helen's identity and her continuous resistance for "The blurring of colonial social categories signaled by Helen's transgressive gesture turns the bedroom-the most intimate of spaces-into a liminal and potentially subversive space where colonial, racial, and class binaries are destabilized" (Paravisini,"Helen" 220):

Helen had kept the house

as if it were her own, and that's when it all begins:

when the maid turns into mistress and destroys her own possibilities. They start to behave

as if they owned you. Maud said. This was the distress of the pale lemon frock, which Helen claimed Maud gave her but forgot. He stayed out of it, but that dress had an empire's tag on it, mistress to slave.

The price was envy and cunning.(64)

These lines demonstrate Walcott's views as a postcolonial writer who regards the cultural identity as the key to the Caribbean lives and that the folk culture is vital in 
understanding the Caribbean identity. The previous part presents the colonial race, class and gender prejudice and its discriminatory relationship with Helen. The inclusion of the line, "They start to be behave as if they owned you" asserts the colonial power in dominating the colonized and therefore "the price was envy and cunning". Walcott succeeds through the use of metaphors to signify this feeling of distress, suffering and pain of the colonized who are internalized the idea of being possessed by the colonizers who represent their masters.

In choosing the epic form for Omeros, Walcott seeks to create a common mythology for the Caribbean society, which is characterized mainly by the multiplicity of races, cultures, ethnicities and languages (French, Spanish, Dutch and English) that are spoken in the Caribbean society. "He was drawn to Creole. Creoles were newer and therefore more vigorous, more alive, more natural. More than this, Creolization was one way...in which slaves were able to resist...Creole therefore has symbolic importance beyond its role as the language of people" (Barnard 60).

Omeros shows St. Lucia as a pluralist Caribbean society, where different cultures, languages and races intermingle. Moreover, the racial and linguistic diversity came as a result of European colonialism and slave trade. The poem is considered to be Walcott's tribute to his homeland, St.Lucia. it is not just a poem, it is a cultural anthology of the Caribbean. It presents multicultural and multiracial diverse people of different races, classes and genders. It is considered a full record of Walcott's life, the life of St.Lucia and a faithful portrait of the Caribbean experience:

I sang our wide Country, the Caribbean Sea.

Who hated shoes, whose soles were as cracked as a stone, 
Who was gentle with ropes, who had one suit alone, Whom no man dared insult and who insulted no one

Of the Caribbean continue my epilogue; may waves remove their shawls as my mourners walk home

to their rusted villages, good shoes in one hand. (Omeros 321)

This part demonstrates Walcott's celebration of the Caribbean Sea, the life of St. Lucia, its people, its landscape and its language. Therefore, he goes through the conflict between the early and later stages and between Africa which represents an origin and Europe which implies the new world. His major concern is to place the Caribbean canon in the whole context of the world through presenting " the deep hymn of the Caribbean".

In Omeros, Walcott employs the St. Lucian dialect to represent the uniquely Caribbean identity. By employing multiple accents and languages, Walcott therefore creates a new nationhood of the multicultural Caribbean society. The role of language in representing the Caribbean traits is evident in portraying characters who have the power of language. As a spokes-person of the poet, Achille realized the importance of speaking his language:

\section{"Make me happier,}

Make me forget the future." He laughed whenever the men laughed in their language which was his

also. They entered the river, waist-deep. They spread in a half-circle, with the looped net. There was peace on the waveless river, but the surf roared in his head. (Omeros141) 
Living among the creole speaking people, makes the poet "happier" and makes him "forget the future". In writing about his people and their language, the poet changes the use of words to reveal his pleasure. In this way, Caribbean people reclaim their ancestral heritage and traditions as a way that assert their cultural identity which is represented in the aspects of race, language and nation.

Although Walcott left his homeland, he continued to depict the colonized Caribbean conditions throughout his works. Furthermore, his life on St.Lucia helped him in creating a setting for this colonial experience. As he experienced the effects of colonialism, Walcott succeeds in employing every aspect of the Caribbean society to reflect its brutality. He tries through the use of personifications and the metaphors to portray an awful image of the colonizers:

With his cutlass he made A swift sign of the cross, his thumb touching his lips while the height rang with axes. He swayed back the blade,

and hacked the limbs from the dead god, knot after knot, wrenching the served veins from the trunk as he prayed:

"Tree! You can be a canoe! Or else you cannot(Omeros 6)

Walcott employs personification in the previous lines to stress the impact of colonialism and the exploitation of the colonizers. As Paravisini points out that: "The ritualistic cutting of the trees, in which the trees are personified, is depicted in the text as symbolic of the exploitation of nature by the conquerors that followed on the discovery of the island by European in 1500" (Paravisini, Literature 218). In writing Omeros, Walcott turns his attention to the historical, social and 
political forces shaping the Caribbean culture and identity. He employs various narrative modes in the poem to cover his different themes. "Walcott maintains the continuity of Omeros on every level, from the prosody and underlying imagery to the various complementary narrative threads and interlocking themes"(Hamner, Epic of the Dispossessed 73).

Omeros, then, celebrates the cultural traditions of the Caribbean by recounting the St. Lucian history and heritage. The poem is an important Caribbean reference in the history of the Caribbean literature as it investigates the search for a West Indian heritage that will give the Caribbean people their cultural identity. In this work, Walcott raises the Caribbean problem of the cultural identity through creating real Caribbean characters and giving them heroic traits. Moreover, the use of the persona of the poem varies from first person to third person in order to address most of the St. Lucian society. The persona in Walcott's Omeros and the use of pronouns pass through different stages of development where the adoption of persona, and the use of other voices become dominant modes in Walcott's Omeros.

\section{All history}

In a dusty Beefeater's gin. We helped ourselves

To these green islands like olives from a saucer,

Munched on the pith, then spat their sucked stones on a plate,

Like a melon's black seeds. Pro honoris causa, But in whose honour did his head-wound graduate?

(Omeros 25)

Using the first person pronoun in "we helped ourselves" reveal the commonness of the Caribbean feelings. St.Lucia has a colonial history; it was colonized by the French and the British 
Empires for many centuries. The Caribbean history of colonialism is reflected in the narratives and themes of Omeros. Therefore, the poem exposes how the effects of colonialism on the oppressed Caribbean people are never fully alleviated even with the passing of time and that the colonial past has never been forgotten as the indigenous St.Lucian people and their culture were displaced by the British colonialization.

As a pluralistic and a multicultural society, St.Lucia is full of different stories of multiracial and multicultural groups of people. Through Omeros, Walcott invites the Caribbean people to see themselves as part of this community. The poem reflects the inherent connection between his verse forms(such as meter, rhyme and metaphor) and the different themes of diaspora and identity crisis:

Because strong as self-healing coral, a quiet culture is branching from the white ribs of each ancestor,

deeper than it seems on the surface; slowly but sure, it will change us with the fluent sculpture of Time, it will grip like polyp, soldered by the slime of the sea-slug

from that coral and crystalline origin, a simply decent race broke from its various pasts, from howling sand to a track in a forest, torn from the farthest places(296-7)

The previous part shows Walcott's main interest to connect all the people of St.Lucia together because what connects them is "deeper than it seems on the surface" and that healing is the way to transcend any division and difference in the Caribbean society. These lines convey Walcott's broader aim of creating a new race without any racial or class distinction. The use of metaphors serves the meaning and helps in understanding Walcott's implied meanings as when he says: "it will change 
us" and "it will grip like polyp". Walcott deals with the cultural healing as the magic stick that will change the Caribbean people who were fragmented and displaced to be connected and unified society.

Omeros is left to assert Walcott's endeavor to demonstrate the St.Lucian society as a new world and that the Caribbean characters create new identities and the West Indies is portrayed as being various and distinctive place for different people. The final scene of the variety of birds in Maud's funeral are emblematic of the multiculturalism in the Caribbean society:

And those birds Maud Plunkett stitched into her green silk with sibylline steadiness were what islands bred: brown dove, black grackle, herons like ewers of milk pinned to a habitat many had adopted The lakes of the world have their own diaspora of birds every winter, but these would not return. The African swallow, the finch from India now spoke the white language of a tea-sipping tern, with the Chinese nightingale on a shantung screen,

while the Persian falcon, whose cry leaves a scar on the sky till it closes, saw the sand turn green, the dunes to sea, understudying the man- o'-war,(Omeros 313)

The birds represent the diverse cultures- African, Indian, English, Persian and Chinese. The final lines of the poem sum up the multicultural mixture and the Caribbean diversity and hybridity. The use of metaphor in the first line, "And those birds Maud Plunkett stitched into her green silk" indicates the interconnectedness of the Caribbean diversity. Consequently, the poem presents the broad range of various stories of different St.Lucian characters who share the same pain, loss and 
displacement among each other. Some characters share the same language, history and origin. Moreover, most of the characters are the ordinary and simple Caribbean characters whose dreams are as simple as their life. They are always portrayed looking for their cultural identities. Walcott doesn't distort the simple reality of the West Indies through presenting great epic heroes, on the contrary, he stresses the simplicity of the ordinary Caribbean characters who represent the everyday characters.

Walcott makes good use of the classical forms and language to fit them for the representations of the Caribbean character. The poem helps the Caribbean people to define their past and to envision their future heritage:

talking the marine dialect of the Caribbean with nightjars, finches, and swallows, each origin enriching the islands to which their cries were sewn.

Across the bay the ridge bristled once with a fort, then the inner promontory itself; its shipping was martial then, its traffic in masts the swift fleet(313-14)

The poem, therefore, supports the Caribbean protest while at the same time develops Walcott's art forms that demonstrate the Caribbean uniqueness and individuality through employing the "dialect of the Caribbean". The language employed by Walcott provides the reader with historical and cultural background and manipulates different social themes into the continuing dialogue. Through Omeros, Walcott invites the reader to 
envision history in a new different way through his use of language and choice of words. The language is developed out of his own Caribbean experience and his multicultural heritage and it is woven out of the Caribbean dialect and the standard English. Furthermore, his use of English does not imply his acceptance of colonialism. He declares that: "I do not consider the English language to be the language of my masters. I consider language to be my birthright. It is mine to do what other poets before me did, which is to fuse the noble and the common" (Walcott, Conversations 82).

As he ends the long epic, the narrator stresses the idea that the Caribbean can keep his old traditions and language which are represented in Africa. The Caribbean people's struggle and the long history of colonialism and their insistence to keep their identity, "make a return to the ancestral world possible"(Paravisini, Literature 230). Walcott achieves this return through his use of Creole language, which came from the cultural contact between European colonizers and the African slaves. He incorporates Creole in his work to celebrate the ethnic diversity and the orality of the indigenous people as Creole is the first language of the majority of people in the Caribbean. Moreover, it was challenging for Walcott to employ Creolization in his poetry.

As it is a postcolonial text, Omeros echoes colonialism and the history of the Caribbean with the racial hegemony in St.Lucia and the history of the colonies. The main setting for Walcott's Omeros is St.Lucia which provides the poet's backdrop and his birth place. Themes of alienation, subjugation and racial domination are central to the poem. As a multicultural and multiracial society, the community of St.Lucia provides conflicting views regarding the history, the culture and the race of the characters. The mixing of races, classes, cultures and colonialism has a great impact on the 
creolized society. Walcott achieves uniqueness and newness in writing Omeros in Cantos. The inclusion of Caribbean vernacular and the interweaving of St. Lucian Creole and standard English presents Walcott's challenge in producing a modern epic.

In conclusion, Omeros not only represents the stories of the St.Lucian community, but it helps understanding the greater community of the West Indies. Therefore, Walcott's aim is to identify the Caribbean identity through demonstrating its different aspects of race, class, religion and nation. The poem, then, concerns with the formation of the Caribbean community that extend beyond the community of St. Lucia. Many characters in Omeros reflect the Caribbean resistance against all aspects of colonialism. Consequently, The poem is a Caribbean epic which weaves together Walcott's quest to celebrate the Caribbean identity and it presents the history of St.Lucia in a unique form that had never been written in any such form. Although Omeros doesn't have all the features of a classical epic, it has its own hybrid genre. It concerns mainly with questions of the Caribbean cultural and national identity. It answers the questions of cultural identity in postcolonial context, traces the history of St.Lucia and seeks to identify the West Indian heritage. Therefore, Omeors implies Walcott's representation of the Caribbean community through presenting a conventional story of the postcolonial society. Using the Caribbean folk, Walcott portrays the stories of his people who endeavor to re-establish their cultural identity.

\section{Conclusion}

Omeros not only represents the stories of the St.Lucian community, but it helps understanding the greater community of the West Indies. Although Omeros doesn't have all the features of a classical epic, it has its own hybrid genre. It concerns mainly with questions of the Caribbean cultural and 
national identity. It answers the questions of cultural identity in a postcolonial context, traces the history of St.Lucia and seeks to identify the West Indian heritage. Therefore, Omeors implies Walcott's representation of the Caribbean community through presenting a conventional story of the postcolonial society. Using the Caribbean epic, Walcott portrays the stories of his people who endeavor to re-establish their cultural identity.

\section{Works Cited}

Barnard, Don. Walcott's Omeros: A Reader's Guide. Boulder \& London: First forum Press, 2014. Print.

Bery, Ashok. Cultural Translation and Postcolonial Poetry. Palgrave: Macmillan, 2007. Print.

Callahan, Lance. In the Shadows of Divine Perfection: Derek Walcott's Omeros.William Cain, ed. New York \& London: Routledge, 2003. Print.

Fanon, Frantz. Black Skin, White Masks. Trans. Richard

Philox. New York, Grove Press, 1967. Print.

Fanon, Frantz, Sartre, Jean-Paul, and Farrington, Constance. The Wretched of the Earth. Pref. by Jean-Paul Sartre. Translated from the French by Constance Farrington. New York: Grove, 1968. Print.

Fumagalli, Maria Cristina. The Flight of the Vernacular:

Seamus Heaney, Derek Walcott and the Impress of

Dante. New York: $\quad$ Rodopi B.V., 1994. Print.

Hamner, Robert D., Derek Walcott. New York: Twayne Publishers, 1993. Print

- - - Epic of the Dispossessed: Derek Walcott's Omeros. Columbia and London: University of Missouri Press, 1997. Print.

Henriksen, Line. Ambition and Anxiety: Ezra Pound's Cantos and Derek Walcott's Omeros as TwentiethCentury Epics. Amsterdam-New York, NY, 2006. Print. 
Lagapa, Jason. "Swearing at--Not by--History: Obscenity, Picong and Irony in Derek Walcott's Poetry." College Literature, vol. 35 , no. 2, 2008, pp. 104-125.

Web.https://www-jstor-

org.ezproxy.lib.ou.edu/stable/25115495

Paravisini-Gebert, Lizabeth. "Helen in Her Yellow Dress". The Cross- Dressed Caribbean: Writing, Politics, Sexualities. Fumagalli, Maria Cristina and et al, eds, Charlottesville and London: University of Virginia Press, 2013. Print.

- - - Literature of the Caribbean. Westport: Greenwood Press, 2008.

Penelope, Julia. Speaking Freely: Unlearning the Lies of the Father's Tongue. Elmsford, NY: Peramon Press, 1990. Print.

Ramazani Jahan. The Hybrid Muse: Postcolonial Poetry in English. Chicago: The University of Chicago Press, 2001. Print.

- - - "The Wound of History: Walcott's Omeros and the Postcolonial Politics of Affliction" PMLA. 122.3 (May 1997): 405-17. Web.https://www-jstororg.ezproxy.lib.ou.edu/stable/462949

Ravizza, Eleonora Natalia. Exile and Return as Poetics of Identity in Comtemporary Anglo-Caribbean Literature: Becoming Home. UK: Cambridge Scholars Publishing, 2019. Print.

Rotella, Guy. Castings: Monuments and Monumentality in poems by Elizabeth Bishop, Robert Lowell, James Merrill, Derek Walcott, and Seamus Heaney. Nashville: Vanderbilt University Press, 2004. Print.

Roy, Sneharika. The Postcolonial Epic: From Melville to Walcott and Ghosh. London and New York: Routledge, 2018. Print. 


\section{Derek Walcott's Omeros: A postcolonial Caribbean Epic}

Said, Edward. Culture and Imperialism / Edward W. Said. 1st Vintage Books ed. New York: Vintage, 1994. Print.

Terada, Rei. Derek Walcott's Poetry: American Mimicry.

Boston: $\quad$ Northeastern University Press. 1992. Print.

Walcott, Derek. Conversation with William Baer. Fourteen on Form: $\quad$ Conversations with Poets. Ed. William Baer. The United States of America: The University Press of Mississippi. 1984. Print.

- - - Omeros. New York: Farrar, Straus and Giroux, 1990. Print.

Zargarzadeh, Haleh. "Rhiz(h)Oming Achille: Walcott, Glissant, and the Politics of Relation and Creolization." Journal of Postcolonial Writing, vol. 53, no. 6, 2017, pp. 715-728. Web.

https://doi-org.ezproxy.lib.ou.edu/10.1080/17449855.2017.1322303

Zoppi, Isabella Maria. “'Omeros', Derek Walcott and the Contemporary Epic Poem." Callaloo, vol. 22, no. 2, 1999, pp. 509-528. Web.https://www-jstororg.ezproxy.lib.ou.edu/stable/3299499 